\title{
Effect of Wirefeed Rate On The Morphology Of A Surface Machined Using WEDM
}

\author{
Katerina Mouralova ${ }^{1}$, Jiri Kovar ${ }^{1}$, Libor Benes ${ }^{2}$, Karel Osicka ${ }^{1}$ \\ ${ }^{1}$ Faculty of Mechanical Engineering, Brno University of Technology. Technicka 2896/2, 61669 Brno. Czech Republic. \\ E-mail: mouralova@fme.vutbr.cz, kovar@fme.vutbr.cz, osicka@fme.vutbr.cz \\ ${ }^{2}$ Faculty of Production Technology and Management, J. E. Purkyne University in Usti nad Labem. Pasteurova 3334/7, \\ 40001 Usti nad Labem. Czech Republic. E-mail: benes@fvtm.ujep.cz
}

Wire electrical discharge machining (WEDM) is an unconventional technology of machining that uses physical phenomena for material cutting. During wire electrical discharge machining craters are formed on the workpiece surface, and blended and molten material of both workpiece and wire electrode get stuck here due to diffusion processes. The study deals with the assessment of the influence of wire feed rate on quantitative and qualitative evaluations of craters on the workpiece made of X155CrVMo12-1 alloy tool steel. The diffusion phenomena that had occurred on the surface during the process of cutting were studied using light microscopy. Attention was also given to the detail study of the used brass electrode where the level of wear and degradation in terms of the quality of morphology were studied after the process of cutting.

Keywords: WEDM, Electrical Discharge Machining, steel X155CrVMo12-1, surface layer, wire feed

\section{Acknowledgement}

This work is an output of research and scientific activities of NETME Centre, supported through project NETME CENTRE PLUS (LO1202) by financial means from the Ministry of Education, Youth and Sports under the „National Sustainability Programme I“.

This Part of work was carried out with the support of core facilities of CEITEC - Central European Institute of Technology under CEITEC - open access project, ID number LM2011020, funded by Ministry of Education, Youth and Sports of the Czech Republic under the activity Projects of major infrastructures for research, development and innovations.

This work was supported by the Ministry of Education, Youth and Sport of the Czech Republic, the program NPU1, project No. LO1207.

\section{References}

[1] KNIGHT, A., BOOTHROYD, G. (2005). Fundamentals of metal machining and machine tools. Third Edition, CRC Press, ISBN 1574446592.

[2] JAIN., V. (2009). Advanced machining processes. Allied Publishers, ISBN 8177642944.

[3] OSIČKA, K., FIŠEROVÁ, Z., OTOUPALÍK, J. (2015). Influence of cutting tool overhangs at machining of hardened steels. In: Manufacturing TECHNOLOGY, pp. 188-191.

[4] MOURALOVÁ, K.; BEDNÁŘ, J.; KOVÁŘ, J.; MACH, J. (2016). Evaluation of MRR after WEDM depending on the resulting surface. In: Manufacturing TECHNOLOGY, pp. 396-401.

[5] BLECHA, P.; BLECHA, R.; BRADÁČ, F. (2011). Integration of Risk Management into the Machinery Design Process. In Mechatronics Recent Technological and Scientific Advances. Varšava: Springer- Verlag Berlin Heidelberg, pp. 473-482.

[6] BLECHA, P.; PROSTREDNIK, D. (2011). Influence on the failure probability. Inteligent Manufacturing and Automation: Focus on Young Researches and Scientists, pp. 11-12.

[7] BLECHA, P. (2006). Integration of risk management into Meta- Quality Deployment method. In AEDS 2006 Workshop Proceedings. Plzeň: Západočeská univerzita v Plzni, pp. 23.

[8] MIČIETOVÁ, A., NESLUŠAN, M., ČILLIKOVÁ, M. (2013). Influence of surface geometry and structure after non-conventional methods of parting on the following milling operations. In: Manufacturing TECHNOLOGY, pp. 199-204.

[9] MAŇKOVÁ, I., VRABEC, M., KOVAC, P. (2013). Artificial Neural Network Application for Surface Roughness Prediction when Drilling Nickel Based Alloy. In: Manufacturing TECHNOLOGY, pp. 193-199.

[10] NOVAK, M., DOLEZAL, R. (2012). G-Ratio in hardened steel grinding with different coolants. In: Manufacturing TECHNOLOGY, pp. 192-197. 
[11] LIAO, Y. S., CHEN, S. T., \& LIN, C. S. (2004). Development of a high precision tabletop versatile CNC wireEDM for making intricate micro parts. Journal of micromechanics and microengineering, 15(2), pp. 245.

[12] MATOUSEK, R., BEDNAR, J. (2009). Grammatical Evolution: Epsilon Tube in Symbolic Regression Task. Mendel Journal series. MENDEL. Brno, BUT, pp. 9 - 15.

[13] MATOUSEK, R., BEDNAR, J. (2010). Grammatical evolution and STE criterion: Statistical properties of STE objective function.Lecture Notes in Electrical Engineering, vol 68, pp. 131-142.

[14] LUO, Y. F. (1995). An energy-distribution strategy in fast-cutting wire EDM. Journal of materials processing technology, 55(3), pp. 380-390.

[15] DAUW, D. F., \& ALBERT, L. (1992). About the evolution of wire tool performance in wire EDM. CIRP AnnalsManufacturing Technology, 41(1), pp. 221-225.

[16] SCOTT, D., BOYINA, S., \& RAJURKAR, K. P. (1991). Analysis and optimization of parameter combinations in wire electrical discharge machining. THE INTERNATIONAL JOURNAL OF PRODUCTION RESEARCH, 29(11), pp. 2189-2207.

[17] LIAO, Y. S., HUANG, J. T., \& SU, H. C. (1997). A study on the machining-parameters optimization of wire electrical discharge machining. Journal of Materials Processing Technology, 71(3), pp. 487-493.

[18] GÖKLER, M. I., \& OZANÖZGÜ, A. M. (2000). Experimental investigation of effects of cutting parameters on surface roughness in the WEDM process. International journal of Machine tools and manufacture, 40(13), pp. 1831-1848.

[19] TOSUN, N., COGUN, C., \& INAN, A. (2003). The effect of cutting parameters on workpiece surface roughness in wire EDM. Machining science and technology, 7(2), pp. 209-219.

[20] OBARA, H., IWATA, Y., \& OHSUMI, T. (1995). An attempt to detect wire temperature distribution during wire EDM. In Proceedings of the Eleventh International symposium for Electro-Machining (ISEM-11), Lausanne, Switzerland.

[21] DEKEYSER, W., SNOEYS, R., \& JENNES, M. (1985). A thermal model to investigate the wire rupture phenomenon for improving performance in EDM wire cutting. Journal of Manufacturing Systems, 4(2), pp. 179-190.

[22] MOURALOVA, K., (2015). Modern technologies for wire electrical discharge cutting of metal alloys. Thesis. Brno: CERM, pp. 98.

[23] YANG, X., FENG, G., \& TENG, Q. (2012). Temperature field simulation of wire electrode in high-speed and medium-speed WEDM under moving heat source. Procedia CIRP, 1, pp. 633-638.

[24] KUMAR, A., KUMAR, V., \& KUMAR, J. (2013). Experimental Investigation on material transfer mechanism in WEDM of pure titanium (Grade-2). Advances in Materials Science and Engineering, 2013.

[25] KUMAR, A., KUMAR, V., \& KUMAR, J. (2013). Multi-response optimization of process parameters based on response surface methodology for pure titanium using WEDM process. The International Journal of Advanced Manufacturing Technology, 68(9-12), pp. 2645-2668.

[26] HUANG, C. A., HSU, F. Y., \& YAO, S. J. (2004). Microstructure analysis of the martensitic stainless steel surface fine-cut by the wire electrode discharge machining (WEDM). Materials Science and Engineering: A, 371(1), pp. 119-126.

[27] HUANG, C. A., HSU, C. C., \& KUO, H. H. (2003). The surface characteristics of P/M high-speed steel (ASP 23) multi-cut with wire electrical discharge machine (WEDM). Journal of Materials Processing Technology, 140(1), pp. 298-302. 